\title{
ポリアクリロニトリル膜による血清アルブミン值の改善効果
}

\author{
松本 義弘 小野 丞二 酒井 謙* 水入苑生* \\ 長谷川昭* \\ ツルミ東邦クリニック＼cjkstart東邦大学大森病院腎臓科*
}

key words：クプロファン膜, ポリアクリロニトリル膜, 血清 albumin 值, 生体適合性

〈要旨〉

糖尿病性腎症による慢性腎不全透析患者の生命予後は一般に不良である。この糖尿病患者における栄養状態の改 善を透析方法から目指すエ夫として生体適合性膜である積層型のポリアクリロニトリル膜 (polyacrylonitril) (AN 69

膜）を用いた血液透析を行うことにより，血清 albumin 值に改善が認められるか否かを検討した。

対象は informed consent の得られた安定した残存腎機能のない糖尿病性腎症透析患者 (NIDDM) 9 例とし, 最初 にクプロアンモニウムレーヨン膜（cuprammonium rayon）による血液透析を 6 か月間行い, 引き続いて AN 69 膜 に変更しさらに 6 か月間観察した。 この期間透析時間, 透析液流量, 処方内容, 食事指導内容に変更はなかった。

AN 69 膜に変更後, 血中 $\beta_{2}$-microgloburin $\left(\beta_{2}-M G\right)$ 值は Cu 膜で $36.0 \pm 10.5 \mathrm{mg} / l$, AN69 膜では $29.0 \pm 8.0 \mathrm{mg} /$ $l(\mathrm{p}<0.05)$ と有意に低下し, 血清 albumin 值は Cu 膜で $3.68 \pm 0.27 \mathrm{~g} / \mathrm{d} l, \mathrm{AN} 69$ 膜では $3.91 \pm 0.22 \mathrm{~g} / \mathrm{d} l(\mathrm{p}<0.05)$ と有意に増加した $(n=9)$ 。この間体重の増減, body mass index, \%クレアチニン産生速度, protein catabolic rate (nPCR) の増加はなく, Kt/Vurea, $\mathrm{HbA}_{1 \mathrm{c}}$ にも変化はなかった.

従ってこの $\mathrm{nPCR}$ の変化を伴わない血清 albumin 值の上昇は, AN69 膜の生体適合性による蛋白合成能の改善に 起因するものではないかと推測された。

\section{Improved serum albumin level by a polyacrilonitrile membrane in diabetic hemodialysis patients}

Yoshihiro Matsumoto, Joji Ono, Ken Sakai*, Sonoo Mizuiri*, Akira Hasegawa*

Tsurumi Toho Clinic and Nephrology Department of Toho University*

Poor patient outcome is well known in the diabetic ESRD (end stage renal disease) population. This study was aimed to determine the effect of a biocompatible membrane (polyacrilonitrile ; AN69) on the patient's nutritional status. Nine randomized diabetic hemodialysis patients appeared with informed consent in our institution. They were dialyzed with a cuprammonium rayon membrane for the first 6 months as a control period, and then the membrane was switched to AN69 and the patients were dialyzed for another 6 months.

Dialysis time, dialysate flow, and content of diet education remained constant throughout the study period (12 months). The data of these two periods were compared on the basis of the group mean of every 3 months (mean $\pm S D$ ). The results showed that the serum albumin level was increased from $3.68 \pm 0.27$ to $3.91 \pm 0.22$ $\mathrm{g} / \mathrm{d} l$ after switching the membrane while the $\beta_{2}$-microglobulin level was decreased from $36.0 \pm 10.5$ to $29.0 \pm$ $8.0 \mathrm{mg} / \mathrm{l}$. In this study period, their BW, nPCR, Kt/Vurea, and HbA1c remained constant. We concluded that this improvement in serum albumin level with constant nPCR was partly caused by biocompatibility which may lead to protein synthesis.

松本＼cjkstart義弘 ツルミ東邦クリニックテ230 横浜市鶴見区市場東中町 5-11 ツルミハイツ $3 \mathrm{~F}$ (045-502-4114)

〔受付: 平成 9 年 2 月 24 日, 受理: 平成 9 年 7 月 24 日〕 


\section{緒言}

慢性腎不全透析患者の血清 albumin 值は，その生命 予後に関する栄養状態の指標として重要であり ${ }^{1)}, 4.0$ $\mathrm{g} / \mathrm{d} l$ 以下の群では有意に死亡率が高( ${ }^{2}$ ．また糖尿病 性腎症透析患者では非糖尿病性透析患者に比し死亡率 が 2 倍高く ${ }^{3}$ 透析低血圧による透析量の低下や，血糖 コントロール不良による異化六進状態が低栄養状態を 惹起しているものと考えられる。現在糖尿病性腎症透 析患者への透析方法は, 種々の工夫がなされているが, 栄養状態に関する透析方法論からの検討はいまだ少な い. 生体適合性に優れているとされる high performance の透析膜は高い中分子除去率と少ない補体の 活性化により急性腎不全()等の予後に寄与する可能性 が示唆されている。特に生体非適合膜での, 血液が透 析膜に接することにより起こる補体の活性化は種々の サイトカインの惹起を促し, 体蛋白の異化に繫がるこ とが知られている5)。そこで我々はより良い生体適合 膜の使用により栄養状態, 特に血清 albumin 值に変化 があるのかどうかを低栄養状態が予想される糖尿病性 腎症透析患者で検討した。

\section{I. 目 的}

糖尿病性透析患者において，生体適合膜を使用する ことにより, 血清 albumin 值の改善が見られるか否か を検討した。

表 1 透析条件

\begin{tabular}{lcc}
\hline & $\mathrm{Cu}$ 膜観察期 & AN69 膜観察期 \\
\hline 膜面積 $\left(\mathrm{m}^{2}\right)$ & 1.5 & 1.25 \\
血液流量 $(\mathrm{m} l / \mathrm{min})$ & $200 \pm 25$ & $240 \pm 30$ \\
透析液流量 $(\mathrm{m} l / \mathrm{min})$ & 500 & 500 \\
透析時間 $(\mathrm{hr})$ & 4 & 4 \\
\hline
\end{tabular}

\section{II. 方 法}

当施設における informed consent の得られた安定 した残存腎機能のない糖尿病性腎症 (NIDDM) 透析患 者 9 名（前例インシュリンは投与されていなかった） を対象として，クプロアンモニウムレーヨン膜（cuprammonium rayon）（Cu膜）で6 か月間血液透析を 行い観察し，引き続いて積層型のポリアクリロニトリ ル膜 (polyacrylonitril) (AN69) 膜で6 か月間観察し た。 9 例中 8 例においては AN69 膜による観察期をさ らに 6 か月間延長し, AN69 膜継続観察期とした. 1 例 の脱落は中途転院によるものである.

患者の平均年齢は $55.5 \pm 8.7$ 歳 (全例男性), 平均透 析年数は $4.5 \pm 3.5$ 年であった. 透析方法は $\mathrm{Cu}$ 膜にて 一定の血流量, 透析液量, 透析時間による血液透析を 6 か月行い, その後 AN69 膜へ変更し, 血液流量のみを $20 \%$ 増加した (表 1). 今回使用可能であった AN69 膜 は, 膜面積が $1.25 \mathrm{~m}^{2}$ で in vitro のカタログデータで は尿素クリアランスが $\mathrm{Cu}$ 膜 $(191 \mathrm{ml} / \mathrm{min}: \mathrm{Qb} 200$ $\mathrm{m} l / \mathrm{min})$ より低值 $(174 \mathrm{~m} l / \mathrm{min}: \mathrm{Qb} 200 \mathrm{~m} l / \mathrm{min})$ で あったために, $\mathrm{Cu}$ 膜との KT/Vurea を一致させるた めに血流量を変更した。

観察項目は KT/Vurea, protein catabolic rate (nPCR), 透析前の血清 albumin 值, $\beta_{2}-\mathrm{MG}$, 体重, $\mathrm{HbA}_{1 \mathrm{c}}$ ，\%クレアチニン産生速度, body mass index (BMI)を 2 か月ごとに経時的に測定した。測定日は各 月の第 1 週の最初の透析日と 2 回目の透析日とした. KT/Vurea は Daugirdas ${ }^{6)}$, nPCR は Sargent\& Gotch $^{7}$ の計算式を用いた。

統計学的処理は, 各観察開始月より 2 か月ごと連続 3 回の平均值を個々の症例の值とし, 各観察期の 9 例 の mean $\pm \mathrm{SD}$ を求め, 有意差は Student $の t$ 検定で求 めた。

また Cu膜およびAN69 膜観察期の KT/Vurea と 血清 albumin 值, nPCR と血清 albumin 值に相関があ

表 2 透析膜による各パラメーターの変化

\begin{tabular}{|c|c|c|c|}
\hline & $\mathrm{Cu}$ 膜観察期 $(\mathrm{N}=9)$ & AN69 膜観察期（N=9） & AN69 膜継続観察期（N=8） \\
\hline KT/Vurea & $1.20 \pm 0.2$ & $1.31 \pm 0.23$ & \\
\hline nPCR (g/kg/day) & $1.09 \pm 0.29$ & $1.11 \pm 0.29$ & \\
\hline 血清 albumin $(\mathrm{g} / \mathrm{d} l)$ & $3.68 \pm 0.27$ & $3.91 \pm 0.22^{*}$ & $3.98 \pm 0.19^{*}$ \\
\hline$\beta_{2}-\mathrm{MG}(\mathrm{mg} / \mathrm{l})$ & $36.0 \pm 10.5$ & $29.0 \pm 8.0^{*}$ & \\
\hline 体重（kg） & $62.0 \pm 10.7$ & $61.0 \pm 10.4$ & \\
\hline $\mathrm{HbA}_{1 \mathrm{c}}(\%)$ & $7.1 \pm 1.2$ & $7.3 \pm 1.7$ & \\
\hline body mass index & $24.1 \pm 2.5$ & $23.7 \pm 2.4$ & \\
\hline \%クレアチニン産生速度 & $91.7 \pm 22.7$ & $92.8 \pm 25.1$ & \\
\hline
\end{tabular}

* 前 6 か月に比し $p<0.05$ 


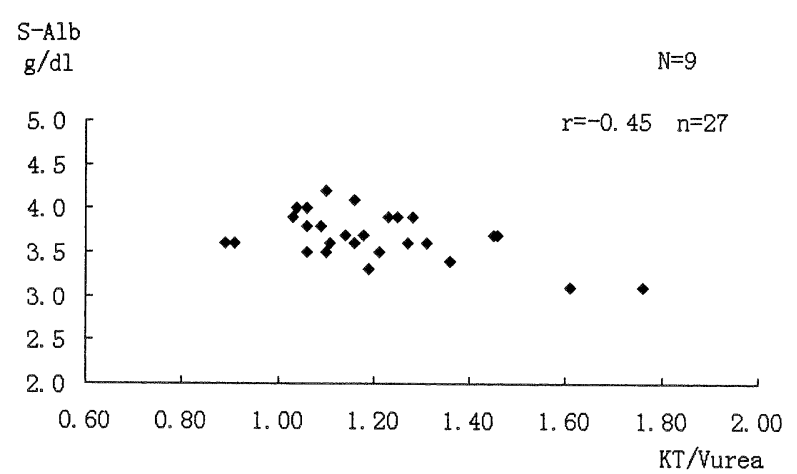

a. KT/Vurea と血清Albumin值 (Cu膜観察期)

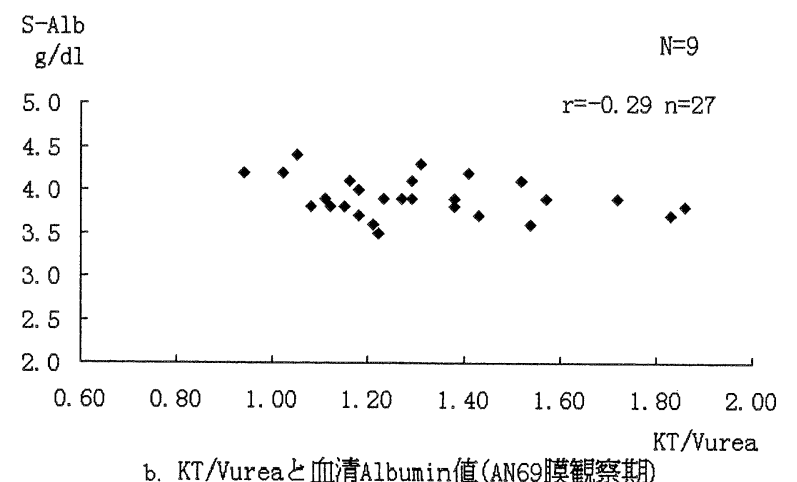

図 1

るか否かを調べた。

\section{III. 結 果}

$\mathrm{Cu}$ 膜観察期 (6 か月), AN69 膜観察期（6 か月）, AN69 膜継続観察期（6 か月）での結果は表 2 に示し た.

KT/Vurea は $1.20 \pm 0.2$ から $1.31 \pm 0.23, \mathrm{nPCR}$ は $1.09 \pm 0.29$ から $1.11 \pm 0.29 \mathrm{~g} / \mathrm{kg} /$ day であり膜変更 前後での透析量と蛋白異化率には有意な変化が認めら れなかった. BMI は24.1土2.5 から $23.7 \pm 2.4 \%$ ，透 析体重は $62.0 \pm 10.7 \mathrm{~kg}$ (最大 $85.6 \mathrm{~kg}$, 最小 $44.9 \mathrm{~kg}$ ) から $61.0 \pm 10.4 \mathrm{~kg}$ （最大 $84.9 \mathrm{~kg}$ ，最小 $44.7 \mathrm{~kg}$ ）と 有意な変化はなく,この間 dry weight の設定変更もな かった.\%クレアチニン産生速度も $91.7 \pm 22.7$ から $92.8 \pm 25.1 \%$ と変化はなかった。従って膜変更前後で は体液量の違いや筋肉量における各種データへの影響 は少ないものと考えられた。この間 $\mathrm{HbA}_{1 \mathrm{c}}$ は $7.1 \pm$ 1.2 から $7.3 \pm 1.7 \%$ と変化はなく, 血糖コントロール は一定に保たれていた。これらのことより 1 年間の観 察期間において透析量, 体重, 血糖コントロールは一 定であり，透析膜のみが変更された因子であった。 $\mathrm{AN} 69$ 膜への変更後, $\beta_{2}-\mathrm{MG}$ は $36.0 \pm 10.5$ から $29.0 \pm 8.0 \mathrm{mg} / l(\mathrm{p}<0.05)$ と有意な低下が見られ, こ の AN69 膜のより高い中分子除去能が観察された．血

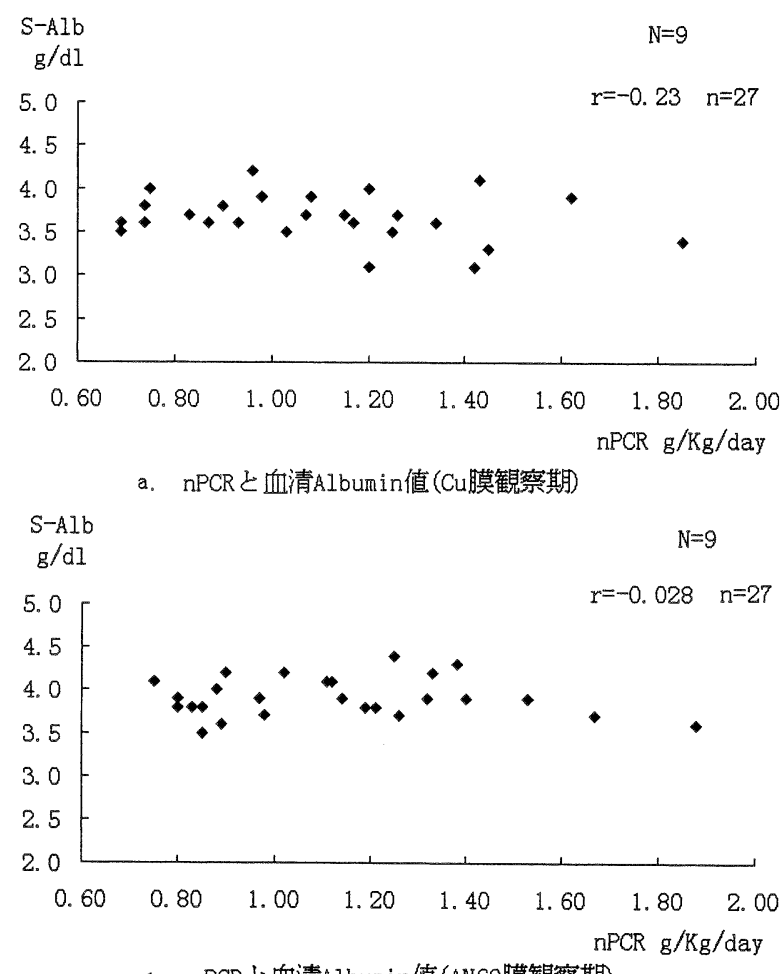

b. nPCR と血清Albumin值 (AN69膜観察期)

図 2

清 albumin 值は $3.68 \pm 0.27$ から $3.91 \pm 0.22 \mathrm{~g} / \mathrm{d} l$ $(\mathrm{p}<0.05)$ と有意な上昇が見られた。この 1 年の観察 期間を越えてさらに 6 か月間 AN69膜にて追加観察 した 8 例における血清 albumin 值は $3.98 \pm 0.19 \mathrm{~g} / \mathrm{d} l$ $(\mathrm{p}<0.05)$ で膜変更前に比し有意な上昇を示した.

KT/Vureaと血清 albumin值の相関を linear regression analysis を用いて見たところ $\mathrm{Cu}$ 膜観察期 は $\mathrm{r}=-0.45 （ \mathrm{n}=27 ）, \mathrm{AN} 69$ 膜観察期は $\mathrm{r}=-0.29$ $(n=27)$ であり, 有意相関は認められなかった(図 $1 \mathrm{a}$, b). 次に $\mathrm{nPCR}$ と血清 albumin 值の関係は, $\mathrm{Cu}$ 膜観察 期 $r=-0.235(n=27), A N 69$ 膜観察期 $r=-0.028$ $(n=27)$ であり，有意相関は認められなかった(図 $2 a$, b).

\section{IV. 考 察}

一般に健常者と比べた場合，透析患者の方が多くの 蛋白摂取を必要とする。その理由として，血液透析自 体がもたらす蛋白の異化分解作用に加えて ${ }^{8)}, 1$ 回の透 析時の透析液中に遊離アミノ酸で $5 \sim 8 \mathrm{~g}$, 総アミノ酸 では 9〜13 g の損失があり，蛋白哀失に結びつくこと が報告されている ${ }^{9)}$. このため透析患者が栄養状態を 保つためにはより多くの蛋白質 $(1.0 \sim 1.2 \mathrm{~g} / \mathrm{kg} / \mathrm{day})$ を摂取し，エネルギーも（30〜 $35 \mathrm{Kcal} / \mathrm{kg} / \mathrm{day})$ 十分 摂取することが推奨されている ${ }^{10)}$ 。しかし実際には良 
好な栄養状態を維持することは難しい．特に糖尿病性 透析患者は, 血糖コントロールの必要上エネルギーの 摂取が非常に難しく，低 albumin 血症に繫がるものと 推察され ${ }^{11)}$, 高い致死率の一因になっていると考えら れる。これらのことから糖尿病性透析患者の栄養状態 の改善は急務と考えられる。

本検討では，KT/Vureaに代表される小分子の透析 量が一定のもとで，AN69膜に変更したことにより血 清 albumin 值が増加した. 従って AN69 膜の特徵とし ての中分子除去能と生体適合性のいずれか一方あるい は両方が今回の血清 albumin 值の増加をもたらせた ものと考えられる.

Bergström ら ${ }^{12)}$ は，尿中の中分子物質を抽出し，こ れを ratに与えたところ, dose dependentに食欲が抑 制されたことを報告している。また Lindsay ら ${ }^{13)}$ は， 透析量を増やした時 $\mathrm{Cu}$ 膜に比して AN69膜では $\mathrm{nPCR}$ の増多が見られたと報告している。

本検討でも AN69 膜使用による $\beta_{2}-\mathrm{MG}$ の有意な低 下が示され，中分子物質の透析量が増すことが示され た.しかし, 膜変更前後において nPCR は増大せず, AN69 膜の中分子除去による食欲増多のみでは本検討 での血清 albumin 值上昇の説明は難しい。

血液と透析膜の接触により，補体の活性化（C3a， $\mathrm{C} 5 \mathrm{a})$ や直接的にリンパ球, 単球およびマクロファージ による IL-1, TNF の産生, 分泌が促進されることが知 られている。特にこの血中サイトカインの増加は, プ ロスタグランジン $\mathrm{E}_{2}$ 活性を介して筋組織蛋白の全体 的な異化分解作用を生じることが示唆されている ${ }^{14)}$. Gutierrez ら ${ }^{15)}$ は $\mathrm{Cu}$ 膜を用い健常人に透析液を用い ない血液透析を行い（sham hemodialysis），下肢筋肉 組織からアミノ酸が有意に増加することを示し，また この時 $\mathrm{Cu}$ 膜に比し生体適合膜である AN69 膜ではア ミノ酸放出に何らの変化も認められなかったことを報 告した。従って AN69 膜は蛋白異化を抑える働きがあ るといえる。また Kaysen ら ${ }^{16)}$ は，血液透析患者の低 albumin 血症は主として透析患者の低栄養状態の結果 から生ずるが，この低栄養状態がさらに albumin の合 成を低下させるとしている。さらに血清 albumin 值お よび albumin 合成はフェリチン, CRP， $\alpha_{2}$-macroglobulin 等の急性炎症反応に逆相関を示したと報告し ている. Cu膜による透析に比して AN69膜では血液 と膜の接触による急性炎症反応が抑えられ蛋白合成の 低下を防いだ可能性も考えられる。このように AN69 膜が持つ生体適合性としての利点は蛋白異化抑制と蛋 白合成能改善の 2 つにあといえる。

これらから本検討での AN69膜による血清 albu- $\min$ 值の増加の一成因として, 補体活性化やサイトカ インの増加が抑制され，筋肉からの蛋白異化の減少が 関与した可能性は十分考えられる。しかしAN69膜に より蛋白異化の抑制のみが生じたなら nPCR は減少 するはずであり，本検討の結果とは異なる.

本検討では AN69 膜変更後 nPCR は不変で血清 albumin 值の上昇が見られたので，蛋白合成能の低下 の抑制と考えるのが妥当と思われる。今回筋肉量の指 標として上腕筋囲（AMC）は測定していなかったが, 他の栄養指標である体重, BMI, \%クレアチニン産生 速度の変化が得られなかった点については, 栄養指標 としての血清 albumin 值が最も鋭敏で早期に変化す るのではないかと考えた. 血管内・外の albumin 量の 分布の変化については, 本検討では不明であり今後の 検討を要する.

糖尿病性透析患者におけるAN69膜による血清 albumin 值の上昇は，生体適合性膜の使用により蛋白 合成能の低下が抑制されたためでないかと考えられ， 試みる価值のある方法であると思われたので報告し た。

\section{結＼cjkstart論}

1) 糖尿病性透析患者において Cu膜から AN69 膜 の変更により血清 albumin 值の有意 $(p<0.05)$ な上昇 がみられた。

2 ）この血清 albumin 值の上昇は体重の増減や $\mathrm{nPCR}$ の増加を伴わなかった。 また $\mathrm{KT} / \mathrm{V} や \mathrm{nPCR}$ とも関係しなかった。

本論文は，第 41 回日本透析医学会総会 (名古屋) にて平 成 8 年 7 月 7 日に発表された。

\section{文献}

1) Lowrie EG, Lew NL : Death risk of hemodialysis patients. The predictive value of commonly measured variables and evalution of death rare differences between facilities. Am J Kidney Dis 15 : 458482,1990

2) 日本透析医学会：わが国の慢性透析療法の現況（1995 年 12 月 31 日現在) $275-276,1995$

3）日本透析医学会：わが国の慢性透析療法の現況（1995 年 12 月 31 日現在)。273-274, 1995

4) Schiffl H, Lang SM, Köing A, Strasser T, Haider MC, Held E: Biocompatible membranes in acute renal failure: prospective case-controlled study. Lancet $344: 570-572,1994$ 
5) Bergström J, Alverstrand A, Gutierrez A : Acute and chronic metabolic effects of hemodialysis. In "Proceedings of the International Symposium on Immune and Metabolic Aspects of Therapeutic Blood Purification System", ed Smeby LC, Jorstad S, Wideroe TE, Trondheim S, p254-273, Karger AG, Basel, 1985

6) Daugirdas JT : Bedside formulas for urea kinetics modeling. Contemporary Dialysis \& Nephrology, February 1989

7) Sargent JA, Gotch FA: Mass balance: A quantative guide to clinical nutritional therapy. Am J Diet Ass $75: 547-551,1979$

8) Goodman MN : Tumor necrosis factor induces skeletal muscle protein break down in rats. Am J Physiol 23 : E 727-730, 1991

9) Wolfson M, Jones MR, Kopple JD : Amino acid losses dureing hemodialysis with infusion og amino acids and glucose. Kidney Int $21: 500-506,1981$

10）日本腎藏学会：腎疾患食事療法ガイドライン。1996

11) Krumlovsky FA : Disorders of protein and lipid metabolism associated with chronic renal failure and chronic dialysis. Ann Clin Lab Sci 11:350, 1981

12) Bergstörm J, Mamoun AH, Anderstam B, Södersten $\mathrm{P}$ : Middle molecules isolated from uremic ultrafiltrate and normal urine induce dose-dependent inhibition of appetite in the rat (abstract). J Am Soc of Nephrol 5:488, 1994

13) Lindsay RM, Spanner E, Heidenheim RP, Kortas C, Blake PG : PCR, Kt/V and membrance. Kidney Int 43 (Suppl 41) : s268-273, 1993

14) Baracos V, Rodeman HP, Dinarello CA, Goldberg $\mathrm{AL}$ : Stimulation of muscle protein degradation and prostaglandin $\mathrm{E}_{2}$ release by leukocytic pyrogen (interleukin-1). N Engl J Med 308 : 553-558, 1983

15) Gutierrez A, Alvestrand A, Wahren J, Bergström $\mathrm{J}$ : Effect of in vivo contact between blood and dialysis membrances on protein catabolism in humans. Kidney Int 38:487-494, 1990

16) Kaysen GA, Rathore V, Shearer GC, Depner TA : Mechanisms of hypoalbuminemia in hemodialysis patients. Kidney Int $48: 510-516,1995$ 